\title{
Land Use Effect on Quality of Plateau Soils: A Case Study of Ososo
}

\author{
in Northern Edo State, Nigeria
}

\author{
Paul Orobosa Orobator \\ Emmanuel Ekpenkhio
}

\begin{abstract}
The study examined land use effect on quality of plateau soils, using Ososo in Northern Edo State, Nigeria as a case study. The objectives were to examine the status of soils under the different land uses and evaluate variation in the physicochemical properties of soils among the investigated sites. A total of thirty-six soil samples were collected from secondary forest, cocoa plantation and quarry site at $0-15$ and $15-30 \mathrm{~cm}$ depths. Soil quality indicators were analyzed in the laboratory, while data were examined by descriptive and inferential statistics. Due to the effect of mining activities, quarry site had lower mean values of soil organic matter, total organic carbon, total nitrogen, available phosphorous, effective cation exchange capacity, potassium, copper and manganese while iron, zinc and calcium were lower in secondary forest. However, Na and ECEC were higher in cocoa plantation. The study further revealed that though the examined land uses had varied effects on the soil properties; quarry site impacted the soil quality parameters more negatively compared to the secondary forest and cocoa plantation land use types. Significant variation $(p<0.05)$ in sand, clay and available phosphorous was detected in the topsoil of the different land uses. The research concluded that the status of the soil nutrients was low. To improve the quality of the plateau soils, liming and the use of animal droppings, town refuse ash and plant remains is recommended.
\end{abstract}

Keywords: Land uses; soil quality; impacts; topsoil; subsoil

\footnotetext{
${ }^{1}$ Department of Geography and Regional Planning, Faculty of Social Sciences, University of Benin, Benin City, Edo State, Nigeria Corresponding Author's Email: orobosa.orobator@uniben.edu
}

Received on March 3 ${ }^{\text {rd }}, 2021 /$ Accepted on October 5 ${ }^{\text {th }}, 2021 /$ Published Online December 19, 2021

Ghana Journal of Geography Vol. 13 (3), 2021 pages 22- 41

Doi: https://dx.doi.org/10.4314/gig.v13i3.2 


\section{Introduction}

Soil is a collection of natural bodies occupying a portion of the earth's crust that support plant growth and it possesses some properties because of the cohesive consequence of climate and vegetation that act upon its parent materials (Kellogg, 1960). Young \& Crawford (2004) reported that soil backs biodiversity and plays a vital role in the balance of ecosystems, thereby providing different services that are essential for human wellbeing. Plateau soils develop at high altitudes but the differences in the soil quality will change based on elevation, because of the variances in temperature, water and wind (Simon, et al., 2002). Parr et al. (1992) regarded soil quality as the capability of soil to produce nontoxic and nutritious foods and crops in a sustainable way over a long term and to improve human and animal health without harmfully damaging the natural resource base or the environment.

Land use effects on soil quality can be expressed through modifications and changes in the physicochemical properties (like texture, bulk density, soil $\mathrm{pH}$, manganese, magnesium, sodium, total organic carbon, soil organic matter, phosphorous, total nitrogen, iron, zinc, potassium, copper, effective cation exchangeable capacity etc.) of soil. Lal \& Stewart (2005) posited that since soil quality protection is revered, assessment of soil quality is necessary under different land uses in specific ecosystems. Within each broad stage of land use, each land use type is categorized by its biotic composition and resource management. This can either lead to an upsurge in soil competence through increasing soil organic matter and nutrient storage, as well as aggregate stability and aggregation, or can even deplete the soil of organic matter and associated macro and micronutrients with negative effects on soil fertility (van Noordwijk, 1998). Soil properties and land use are key factors that govern sustainable use of soil (European Commission, 2007). These influences are 
interactive based on systemic principles, where an alteration in one factor instigates a modification on the other.

Specifically, investigations on the quality of plateau soils have been undertaken. Prominent amongst them are: properties, classification and agricultural potential of basaltic soils in semi-arid Nigeria (Kparmwang et al., 1998); soil parent materials and soil properties in two separate catchment areas on the Jos Plateau, Nigeria (Olowolafe, 2002); characterization and classification of soils of Janta Area, Plateau State of Nigeria (Idoga \& Azagaku, 2005); rattle tree (Albizia lebbeck) effects on soil properties and productivity of Irish potato (Solanum tuberosum) on the Jos Plateau, Nigeria (Kareem, 2007); physicochemical properties and selected heavy metals in tin-mine spoil soils around Jos Plateau Nigeria (Ideriah \& Abere, 2017); physicochemical properties and trace elements of soils in Mambilla Plateau of Northeastern Nigeria (Isaac et al., 2018); influence of neem leaf fortified fertilizers on tea (Camellia sinensis) yield and soil chemical properties (Ipinmoroti \& Akanbi, 2019); energy dispersive $\mathrm{x}$-ray fluorescence determination of minor and major elements in soils of Mambilla Plateau Northeastern Nigeria (Isaac et al., 2019) etc.

The idea of soil quality used to evaluate the quality of soil under different land use systems sprung up during the past decades (Ezeaku, 2015) and empirical studies on soil quality under different land uses have revealed the response of soil quality indicators to land use influences. Higher amounts of soil organic carbon content were noted in the abandoned apple orchard, common apple orchard and natural grassland at the 0-20 cm soil layer in the loess plateau of Northern China (Kalhoro et al., 2017). In the Shivaliks of Indian Punjab, forest soils indicated higher bulk density values as compared to soils under cultivated conditions and other land uses (Vashisht et al., 2020). Soil pH values were within the critical levels (6.5-8.5) under different cropping and other land-use systems 
(CLUS) in Dura catchment, Northern Ethiopia (Tesfahunegn \& Gebru, 2020). The concentration of the basic cations was significantly $(\mathrm{P}<0.05)$ influenced by land use types in Kware Local Government Area, Sokoto State, Nigeria (Hayatu et al., 2020). Significantly higher available P was noted in soils under the grazing land as compared to those under cultivated and fallow land in Kersa sub-watershed, eastern Ethiopia (Mulat et al., 2021). In the Fasha District of Konso Zone in Southern Ethiopia, soil organic carbon was significantly $(\mathrm{P} \leq 0.01)$ affected by land use types and soil depth interaction; the highest $(4.86 \%)$ was observed in topsoil of forest land while, the lowest $(1.36 \%)$ was recorded in subsoil of cultivated soil (Tumayro \& Tesgaye, 2021).

Ososo town is known exceptionally for being located on a plateau in Southern Nigeria, characterized with extensive rocks and hills, wide-ranging land uses and scenic ecological features; these geographies attract tourists all through the year. The presence of hills and rocks had overtime stimulated quarrying activities in the area. However, studies on land use effect on the quality of Ososo soils are lacking. This research was set to fill the gap and provide a topical scientific base for successive soil quality studies in the plateau areas of Southern Nigeria. Understanding the effect of land uses on Ososo soils is strategic for biogeographical inquiries if substantial advancement is to be attained in the monitoring of the quality of plateau soils in Southern Nigeria. This study will significantly assist in developing appropriate land use policies and soil management strategies. The investigation aimed to examine land use effect on quality of plateau soils, using Ososo in Northern Edo State, Nigeria as a case study. Hence, this research sought to achieve its objectives by (1) assessing the status of soils under the different land uses and (2) examining variation in the physicochemical properties of soils among the studied land use systems. 


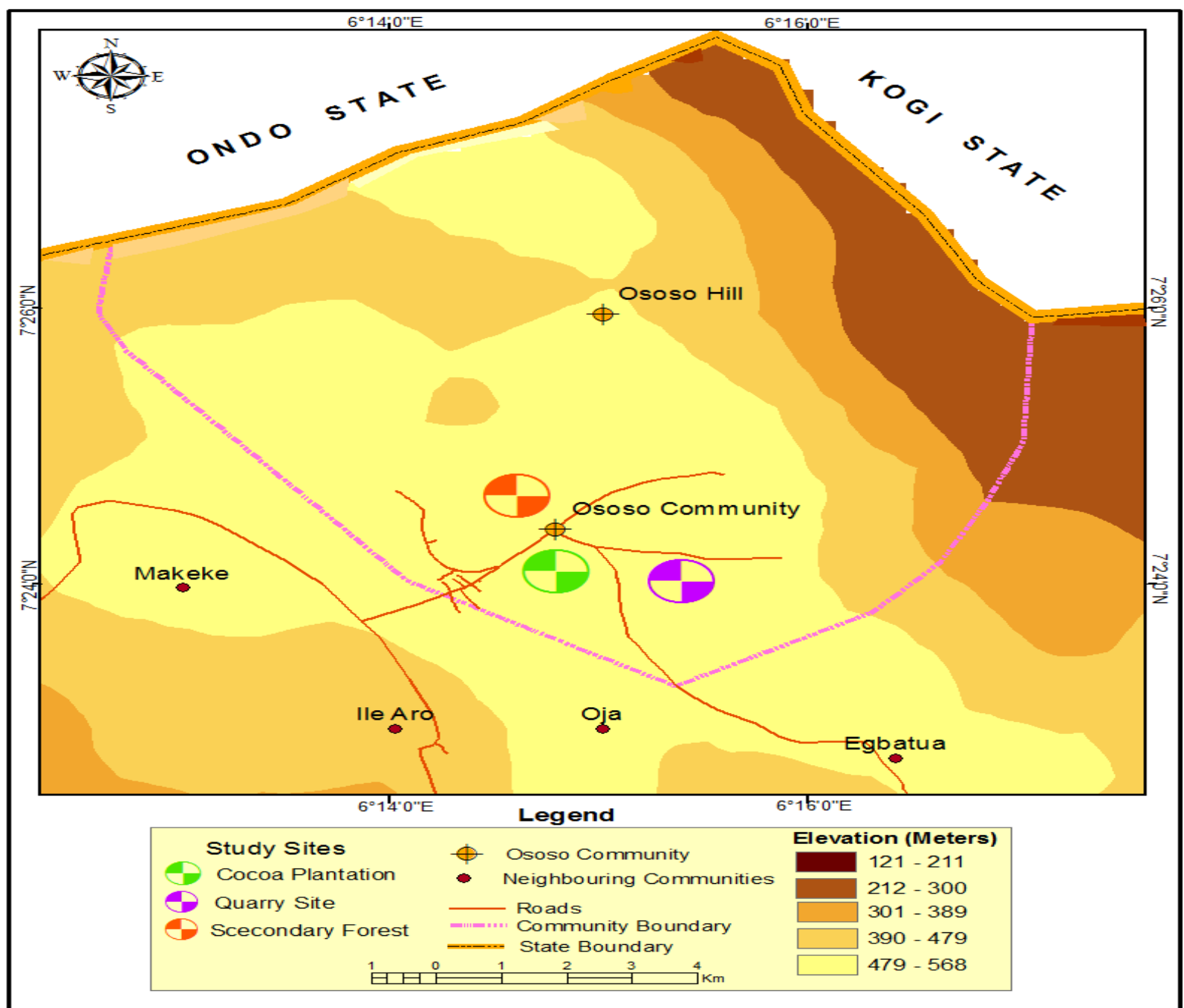

Figure 1: Ososo town showing study sites

Source: Compiled from Open Street Map Database 1.0 (2020)

\section{Materials and methods}

\section{Study area}

Ososo is located within latitudes $6^{\circ} 45 \mathrm{~N}, 7^{\circ} 35 \mathrm{~N}$ and longitudes $5^{\circ} 55 \mathrm{E}, 6^{\circ} 45 \mathrm{E}$ in Akoko-Edo Local Government Area, Edo State, Nigeria (Figure 1). It is characterized by dispersed rocks and undulating hills with an average altitude of approximately $377 \mathrm{~m}(1,236 \mathrm{ft})$ above sea level. Ososo 
soils are granitic in nature and have a very temperate climate similar to that of Jos Plateau, Nigeria. It has a mean monthly temperature range of $20-24^{\circ} \mathrm{C}$ and annual total rainfall of $1400 \mathrm{~mm}$ which falls mostly over a period from April to October (Alexander \& Kidd, 2000). Ososo falls within the tropical rainforest zone and there are anthropogenic forests such as cocoa plantations, cashew plantations etc.

\section{Study sites and soil sampling}

A reconnaissance survey was conducted where secondary forest, cocoa plantation and quarry site were selected for the research. A recently abdicated quarry site was embraced because owners of active quarries did not allow us to collect soil samples. Adopting the systematic random sampling technique, soil samples were collected at a distance of $15 \mathrm{~m}$ apart with the aid of a soil auger. Six (6) soil sampling points were identified in each land use. Soil samples were collected from $0-15 \mathrm{~cm}$ (topsoil) and $15-30 \mathrm{~cm}$ (subsoil). The choice of these sampling depths is because plant nutrients and soil mineralization occurs mostly in the first $30 \mathrm{~cm}$ of the soil profile. Garmin GPSMAP 64st model receiver was used to define the spatial location of sampling points.

\section{Statistical analyses}

The research adopted descriptive and inferential statistics. Descriptive statistics were utilized to aid in describing the data while inferential statistic was used to make generalizations. Analysis of variance (ANOVA) was used to test for significant variation of the physicochemical properties of soils among secondary forest, cocoa plantation and quarry site at $\mathrm{p}<0.05$ level of significance. The analyses were done utilizing statistical analysis software (SAS) package (Coates et al. 2018). 
Ghana Journal of Geography Vol. 13 (3), 2021 pages 22- 41

\section{Laboratory analyses}

Soil textural fractions were analyzed following the Bouyoucos hydrometer method (Pauwels et al. 1992). Bulk density was measured by the core method (Blake \& Hartge, 1986). Soil pH was determined by glass electrode $\mathrm{pH}$ meter (Jackson, 1973). Available phosphorus was determined calorimetrically by molybdenum blue method (Bray \& Kurtz, 1945) while total organic carbon was analyzed by wet oxidation method (Nelson \& Sommers, 1982). Soil organic matter was analyzed by adopting the Walkey \& Black (1934) method and total nitrogen (TN) was determined by the Kjeldahl method. $\mathrm{Ca}$ and $\mathrm{Mg}$ were measured using an atomic absorption spectrophotometer (AAS) while $\mathrm{K}$ and $\mathrm{Na}$ were determined with the aid of flame photometer (USDA, 1972). Effective cation exchange capacity (ECEC) was determined using Ammonium acetate $\left(\mathrm{CH}_{3} \mathrm{COONH}_{4}\right)$ extraction technique (USDA, 1995). The digestion method as described by Francek et al. (1994) was used to analyze $\mathrm{Fe}, \mathrm{Zn}, \mathrm{Cu}$ and $\mathrm{Mn}$.

\section{Results and Discussion}

\section{Soil Texture}

The mean sand value of the subsoil for quarry site $\left(705.90 \mathrm{~g} \mathrm{~kg}^{-1}\right)$ was above $700.00 \mathrm{~g} \mathrm{~kg}^{-1}$, while quarry site had the lowest mean topsoil value of sand $\left(584.80 \mathrm{~g} \mathrm{~kg}^{-1}\right)$. This accounted for significant variation of the mean topsoil values among the examined land uses $(\mathrm{p}<0.05)$ and infers the varied effects of the land uses on the sand content. The soils had more sand content and the textural class is sandy loam. The findings are consistent with those of Senjobi \& Ogunkunle (2011) who reported that sand dominated all the depth of the profiles. The incidence of higher mean sand value in the subsoil (705.90 $\mathrm{g} \mathrm{kg}^{-1}$ ) of quarry site may be due to profile weathering effects through previous 
mining activities on its soil. The lower mean sand value in the topsoil of quarry site may be ascribed to differential segregation by erosion (Tellen et al., 2018). These results do not agree with the findings of Hayatu et al., (2020), in which the highest sand content attained was 910.03 (rainfed arable cropping) and $900.93 \mathrm{~g} \mathrm{~kg}^{-1}$ (grazing). However, they noted that it is because their parent materials were aeolian sand and weathered rock residua. Soils in cocoa plantation had higher mean silt values at both soil depths. This showed the positive effect on silt. The mean values of clay at both soil depths were less than $300.00 \mathrm{~g} \mathrm{~kg}^{-1}$. Olowolafe (2002) stated that this may be credited to the coarse texture and the slow degree of weathering of some mineral contents of granite. In contrast to the findings of the present study, Tesfahunegn and Gebru (2020) observed that the soil clay contents of the cropping and land-use systems (CLUS) varied significantly between 260.00 to $740.00 \mathrm{~g} \mathrm{~kg}^{-1}$. 
Ghana Journal of Geography Vol. 13 (3), 2021 pages 22- 41

Table 1: Range and mean values of physico-chemical properties of soils

\begin{tabular}{|c|c|c|c|c|c|c|c|c|c|c|c|}
\hline \multirow[t]{2}{*}{ Soil parameter } & \multirow{2}{*}{$\begin{array}{l}\text { Depth } \\
(\mathrm{cm})\end{array}$} & \multicolumn{3}{|l|}{ Cocoa plantation } & \multicolumn{3}{|l|}{ Quarry site } & \multicolumn{3}{|l|}{ Secondary forest } & \multirow[t]{2}{*}{ p-value } \\
\hline & & Range & Mean \pm SD & $\begin{array}{l}\text { CV } \\
(\%)\end{array}$ & Range & Mean \pm SD & $\begin{array}{l}\text { CV } \\
(\%)\end{array}$ & Range & Mean \pm SD & $\begin{array}{l}\text { CV } \\
(\%)\end{array}$ & \\
\hline \multirow[t]{2}{*}{ Sand $(\%)$} & $0-15$ & & $693.66 \pm 3.91$ & 5.64 & $523.80-611.10$ & $584.80 \pm 3.19$ & 5.45 & $562.60-717.80$ & $649.40 \pm 6.25$ & 9.62 & $0.00 *$ \\
\hline & $15-30$ & $596.70-695.60$ & $613.40 \pm 4.01$ & 6.12 & $659.60-776.00$ & $705.90 \pm 4.62$ & 6.55 & $552.90-756.60$ & $664.50 \pm 7.07$ & 10.64 & 0.25 \\
\hline \multirow[t]{2}{*}{ Silt (\%) } & $0-15$ & $172.20-256.40$ & $231.30 \pm 3.19$ & 13.83 & $183.30-213.90$ & $204.70 \pm 1.16$ & 5.45 & $196.90-217.00$ & $208.00 \pm 0.83$ & 4.04 & 0.05 \\
\hline & $15-30$ & $97.50-669.80$ & $248.80 \pm 60.69$ & 139.0 & $112.00-244.40$ & $198.90 \pm 6.01$ & 30.25 & $182.10-237.70$ & $209.40 \pm 2.37$ & 11.32 & 0.44 \\
\hline \multirow[t]{2}{*}{ Clay (\%) } & $0-15$ & $11.00 \quad 161.90$ & $75.00 \pm 6.11$ & 81.40 & $175.00-292.90$ & $210.50 \pm 4.30$ & 20.43 & $81.00-240.50$ & $145.90 \pm 6.11$ & 41.95 & $0.00 *$ \\
\hline & $15-30$ & $60.90-254.10$ & $138.20 \pm 8.46$ & 53.47 & $57.20-141.10$ & $95.20 \pm 2.97$ & 31.22 & $61.30-253.60$ & $126.20 \pm 7.08$ & 56.12 & 0.29 \\
\hline \multirow[t]{2}{*}{$\mathrm{BD}\left(\mathrm{Mg} \mathrm{m}^{-3}\right)$} & $0-15$ & $0.98-1.89$ & $1.33 \pm 0.37$ & 27.96 & $0.90-1.67$ & $1.19 \pm 0.28$ & 23.92 & $1.11-1.85$ & $1.37 \pm 0.26$ & 18.76 & 0.57 \\
\hline & $15-30$ & $0.95-1.73$ & $1.45 \pm 0.28$ & 19.25 & $0.89-1.68$ & $1.17 \pm 0.27$ & 22.85 & $0.65-1.85$ & $1.42 \pm 0.44$ & 31.27 & 0.31 \\
\hline \multirow[t]{2}{*}{$\mathrm{pH}$} & $0-15$ & $5.14-5.45$ & $5.30 \pm 0.12$ & 0.02 & $5.11-5.36$ & $5.25 \pm 0.10$ & 1.96 & $4.97-5.41$ & $5.23 \pm 0.17$ & 3.28 & 0.65 \\
\hline & $15-30$ & $4.78-5.27$ & $5.06 \pm 0.19$ & 3.89 & $4.98-5.23$ & $5.12 \pm 0.09$ & 1.77 & $5.01-5.36$ & $5.15 \pm 0.13$ & 2.59 & 0.54 \\
\hline \multirow[t]{2}{*}{$\mathrm{SOM}\left(\mathrm{g} \mathrm{kg}^{-1}\right)$} & $0-15$ & $0.38-3.03$ & $1.65 \pm 1.03$ & 62.66 & $0.55-1.67$ & $0.96 \pm 0.44$ & 45.29 & $0.36-3.53$ & $1.73 \pm 1.37$ & 79.01 & 0.38 \\
\hline & $15-30$ & $0.24-1.47$ & $0.91 \pm 0.48$ & 52.49 & $0.19-1.12$ & $0.69 \pm 0.31$ & 45.59 & $0.26-2.28$ & $1.05 \pm 0.70$ & 67.20 & 0.49 \\
\hline \multirow[t]{2}{*}{ TOC $\left(\mathrm{g} \mathrm{kg}^{-1}\right)$} & $0-15$ & $0.22-1.76$ & $0.96 \pm 0.60$ & 62.76 & $0.32-0.97$ & $0.56 \pm 0.25$ & 45.27 & $0.21-2.05$ & $1.01 \pm 0.79$ & 78.91 & 0.38 \\
\hline & $15-30$ & $0.14-0.85$ & $0.53 \pm 0.28$ & 52.19 & $0.11-0.65$ & $0.39 \pm 0.18$ & 45.59 & $0.15-1.32$ & $0.61 \pm 0.41$ & 67.15 & 0.49 \\
\hline \multirow[t]{2}{*}{$\mathrm{TN}\left(\mathrm{g} \mathrm{kg}^{-1}\right)$} & $0-15$ & $0.03-0.28$ & $0.14 \pm 0.09$ & 68.17 & $0.04-0.12$ & $0.07 \pm 0.03$ & 43.69 & $0.03-0.31$ & $0.14 \pm 0.11$ & 79.79 & 0.34 \\
\hline & $15-30$ & $0.02-0.10$ & $0.07 \pm 0.03$ & 44.79 & $0.01-0.08$ & $0.05 \pm 0.02$ & 48.06 & $0.02-0.16$ & $0.08 \pm 0.04$ & 56.11 & 0.32 \\
\hline \multirow[t]{2}{*}{ Avl P (mg kg $\left.{ }^{-1}\right)$} & $0-15$ & $0.48-7.39$ & $3.44 \pm 2.71$ & 78.85 & $0.40-1.63$ & $0.89 \pm 0.44$ & 49.81 & $0.26-2.46$ & $1.16 \pm 0.83$ & 71.39 & $0.03 *$ \\
\hline & $15-30$ & $0.65-1.75$ & $1.13 \pm 0.39$ & 35.32 & $0.22-2.17$ & $0.81 \pm 0.72$ & 88.85 & $0.54-5.02$ & $1.62 \pm 1.72$ & 106.09 & 0.45 \\
\hline \multirow[t]{2}{*}{$\operatorname{ECEC~}\left(\mathrm{cmol} \mathrm{kg}^{-1}\right)$} & $0-15$ & $0.14-1.32$ & $0.61 \pm 0.54$ & 88.65 & $0.08-0.65$ & $0.25 \pm 0.21$ & 83.67 & $0.08-0.98$ & $0.36 \pm 0.35$ & 98.85 & 0.29 \\
\hline & $15-30$ & $0.31-0.84$ & $0.56 \pm 0.19$ & 35.15 & $0.17-1.64$ & $0.52 \pm 0.56$ & 107.1 & $0.23-0.92$ & $0.53 \pm 0.32$ & 60.60 & 0.98 \\
\hline \multirow[t]{2}{*}{$\mathrm{Ca}\left(\mathrm{cmol} \mathrm{kg}^{-1}\right)$} & $0-15$ & $1.44-16.26$ & $8.29 \pm 5.13$ & 61.86 & $3.77-13.21$ & $8.34 \pm 4.11$ & 49.23 & $3.11-21.75$ & $9.08 \pm 6.74$ & 74.26 & 0.96 \\
\hline & $15-30$ & $1.89-8.67$ & $3.97 \pm 2.54$ & 63.95 & $2.95-8.25$ & $5.36 \pm 1.89$ & 35.41 & $0.99-12.78$ & $5.04 \pm 4.40$ & 87.29 & 0.72 \\
\hline \multirow[t]{2}{*}{$\mathrm{Na}\left(\mathrm{cmol} \mathrm{kg}^{-1}\right)$} & $0-15$ & $7.98-55.38$ & $33.05 \pm 19.44$ & 58.81 & $9.71-28.22$ & $18.75 \pm 6.10$ & 32.56 & $3.95-32.92$ & $18.75 \pm 11.21$ & 59.79 & 0.13 \\
\hline & $15-30$ & $10.64-23.47$ & $15.55 \pm 5.01$ & 32.22 & $7.53-27.02$ & $15.77 \pm 6.95$ & 44.07 & $5.28-26.4$ & $17.02 \pm 9.92$ & 58.27 & 0.93 \\
\hline \multirow[t]{2}{*}{$\mathrm{Mg}\left(\mathrm{cmol} \mathrm{kg}^{-1}\right)$} & $0-15$ & $4.48-31.11$ & $18.57 \pm 10.91$ & 58.82 & $5.46-15.85$ & $10.54 \pm 3.43$ & 32.54 & $2.22-18.49$ & $10.53 \pm 6.29$ & 59.79 & 0.13 \\
\hline & $15-30$ & $5.97-13.19$ & $8.74 \pm 2.82$ & 32.25 & $4.23-15.15$ & $8.86 \pm 3.90$ & 44.07 & $2.97-14.83$ & $9.57 \pm 5.57$ & 58.26 & 0.93 \\
\hline \multirow[t]{2}{*}{$\mathrm{K}\left(\mathrm{cmol} \mathrm{kg}^{-1}\right)$} & $0-15$ & $2.60-35.34$ & $14.24 \pm 11.90$ & 83.57 & $5.51-15.09$ & $8.35 \pm 3.61$ & 43.24 & $1.39-18.24$ & $8.71 \pm 7.14$ & 81.99 & 0.40 \\
\hline & $15-30$ & $3.29-11.98$ & $6.05 \pm 3.19$ & 52.76 & $3.36-7.39$ & $5.09 \pm 1.51$ & 29.63 & $1.29-9.21$ & $4.77 \pm 3.11$ & 65.22 & 0.70 \\
\hline \multirow[t]{2}{*}{$\mathrm{Fe}\left(\mathrm{mg} \mathrm{kg}^{-1}\right)$} & $0-15$ & $24.06-139 . .56$ & $80.83 \pm 47.14$ & 58.32 & $31.22-90.73$ & $61.96 \pm 19.68$ & 31.76 & $12.69-97.82$ & $46.81 \pm 28.62$ & 61.15 & 0.24 \\
\hline & $15-30$ & $34.19-71.59$ & $47.49 \pm 15.10$ & 31.81 & $24.22-84.08$ & $49.92 \pm 21.21$ & 42.49 & $16.97-81.40$ & $44.68 \pm 28.38$ & 63.51 & 0.92 \\
\hline \multirow[t]{2}{*}{$\mathrm{Cu}\left(\mathrm{mg} \mathrm{kg}^{-1}\right)$} & $0-15$ & $1.12-15.2$ & $6.13 \pm 5.12$ & 83.57 & $2.37-6.49$ & $3.59 \pm 1.55$ & 43.22 & $0.60-7.84$ & $3.74 \pm 3.07$ & 82.02 & 0.40 \\
\hline & $15-30$ & $1.41-5.15$ & $2.59 \pm 1.37$ & 52.86 & $1.44-3.18$ & $2.19 \pm 0.65$ & 29.74 & $0.56-3.96$ & $2.05 \pm 1.34$ & 65.07 & 0.70 \\
\hline \multirow[t]{2}{*}{$\operatorname{Mn}\left(\mathrm{mg} \mathrm{kg}^{-1}\right)$} & $0-15$ & $0.35-4.71$ & $1.89 \pm 1.59$ & 83.50 & $0.73-2.01$ & $1.11 \pm 0.48$ & 43.25 & $019-2.43$ & $1.16 \pm 0.95$ & 81.74 & 0.40 \\
\hline & $15-30$ & $0.44-1.60$ & $0.81 \pm 0.43$ & 52.83 & $0.45-0.99$ & $0.68 \pm 0.20$ & 29.64 & $0.17-1.23$ & $0.64 \pm 0.42$ & 65.61 & 0.70 \\
\hline \multirow[t]{2}{*}{$\mathrm{Zn}\left(\mathrm{mg} \mathrm{kg}^{-1}\right)$} & $0-15$ & $0.14-2.45$ & $1.05 \pm 0.95$ & 89.72 & $0.62-1.81$ & $1.24 \pm 0.39$ & 31.82 & $0.25-1.96$ & $0.94 \pm 0.57$ & 61.38 & 0.74 \\
\hline & $15-30$ & $0.68-2.86$ & $1.36 \pm 0.83$ & 60.85 & $0.48-1.68$ & $0.99 \pm 0.42$ & 42.49 & $0.34-1.63$ & $0.89 \pm 0.57$ & 63.55 & 0.42 \\
\hline
\end{tabular}




\section{Bulk density $(B D)$}

BD values decreased from topsoil to subsoil in secondary forest and cocoa plantation in comparison to the quarry site (Table 1). This may be due to less aggregation and root penetration in the subsoil (Bangroo et al., 2017). The BD values observed in quarry site may be attributed to the effect of quarrying machineries. Higher mean BD values observed in both secondary and cocoa land uses may be ascribed to the trampling effect of humans via tree logging and cocoa pods harvesting. The $\mathrm{BD}$ of the soils infer that root growth will not be affected as they were not above $1.63 \mathrm{Mg} \mathrm{m}^{-3}$ which is the threshold BD limit inhibiting root growth (USDA, n.d). Generally, the range of $\mathrm{BD}$ values revealed the varied effects of the examined land uses. This finding is in agreement with Mulat et al.'s (2021) findings which showed similar bulk density values of $1.18 \mathrm{Mg} \mathrm{m}^{-3}$ (grazing), $1.30 \mathrm{Mg} \mathrm{m}^{-3}$ (cultivated) and $1.33 \mathrm{Mg} \mathrm{m}^{-3}$ (fallow land) in eastern Ethiopia. Accordingly, they stated that this may be due to the detected low clay and amount of organic matter content which could also lead to poor soil aggregation.

\section{Soil pH}

The $\mathrm{pH}$ values of the topsoil and subsoil of the land uses as indicated in Table 1, revealed a decreasing order of acidity (cocoa plantation < quarry site < secondary forest). The $\mathrm{pH}$ status of soils vary from very strong acidic to strongly acidic (Landon, 1991). According to Haynes \& Naidu (1998), this will have impact on metal ion solubility, clay dispersion, microbial activity and plant growth. The acidic status of soils may also be due to a high degree of biological activity favoring the formation of $\mathrm{H}_{2} \mathrm{CO}_{3}$ (Brady \& Weil, 2002). The result of the study agreed with Hassan et al. (2015) who reported pH values of less than 5.5 in basaltic soils of Jos Plateau. 


\section{Soil organic matter (SOM)}

As indicated in Table 1, SOM concentrations in soils on the topsoil and subsoil were secondary forest $>$ cocoa plantation $>$ quarry site. The incidences of increased net primary productivity in the secondary forest may account for its higher SOM contents (Griffiths et al., 2009). The lower SOM fractions in cocoa plantation soils deduce the waning effect cultivation has on SOM. The incidences of mining activities may have resulted to the low SOM contents in the quarry site (Ideriah \& Abere, 2017). Although, the variations of SOM among secondary forest, cocoa plantation and quarry site were not significant $(\mathrm{p}<0.05)$, the concentrations of SOM at both soil depths indicated the varied effect of the land uses on SOM. SOM contents decreased down the soil depths; this could be ascribed to the sandy nature of the soils. Similarly, on Jos Plateau, Nigeria, Kareem (2007) reported that SOM contents dwindled with decrease in soil depths.

\section{Total organic carbon (TOC)}

Total organic carbon concentrations in soils on the topsoil and subsoil were quarry site < cocoa plantation < secondary forest (Table 1). The lower contents of TOC in quarry site may be due to insufficiency of vegetation, reduced return of crop residues and mineralization (Hassan et al., 2015). This paucity of vegetation led to less accretion of litter and low input of TOC in soils (Bangroo et al., 2017). Although, no significant variation of TOC was detected among the land uses, the concentrations of TOC depicted the varied degrees of effect. According to Landon (1991), TOC levels below $2 \mathrm{~g} \mathrm{~kg}^{-1}$ (organic matter equivalent of $3.44 \mathrm{~g} \mathrm{~kg}^{-1}$ ) are very low for the tropics. Based on this ranking, the soils in the land uses are low in TOC and SOM. This research aligned with Rhoades (2008) who reported higher values of TOC in forest $\left(8.21 \mathrm{~g} \mathrm{~kg}^{-1}\right)$ followed 
by $\mathrm{Cu}\left(6.33 \mathrm{~g} \mathrm{~kg}^{-1}\right)$ and pasture $\left(5.88 \mathrm{~g} \mathrm{~kg}^{-1}\right)$. The results also agreed with the research work of Meliyo et al., (2016) which showed that forest plantation has higher SOC compared to fallow and cultivated ones in the Usambara Mountains of Tanzania.

\section{Total Nitrogen $(T N)$}

Total Nitrogen levels in soils on the subsoil of the examined land uses were secondary forest > cocoa plantation $>$ quarry site (Table 1). The results also showed that TN did not vary significantly with land use types $(\mathrm{p}<0.01)$. The lower mean values obtained at both soil depths in the quarry site may be due to poor TN retention ability of the soils and loss of SOM (Tellen et al., 2018). The higher TN mean values observed in secondary forest and cocoa plantation suggests the low humification processes (Assen \& Tegene, 2008). SOM, TOC and TN contents showed a similar trend in relation to the order of incidences in the different land uses. This may be hinged on insolation variation with regard to altitude influencing vegetation, soil moisture and temperature regimes (Bangroo et al., 2017). The varied effects of secondary forest, cocoa plantation and quarry site on TN are likely triggered by variations in the rates of decomposition and nitrogen turnover (Yüksek et al., 2013). The difference of TN within sites in particular might be associated with the variability of SOM (Kidanemariam et al., 2012). Nevertheless, the current finding is contrary to an earlier report by Orobator et al., (2019) who obtained a relatively higher content of TN in both the topsoil $\left(0.21 \mathrm{~g} \mathrm{~kg}^{-1}\right)$ and subsoil $\left(0.19 \mathrm{~g} \mathrm{~kg}^{-1}\right)$ of cocoa land use in lowland areas of northern Edo State, Nigeria. 


\section{Available Phosphorus (Avl P)}

Available Phosphorus concentrations in soils on the topsoil were cocoa plantation > secondary forest > quarry site (Table 1). The higher concentrations of Avl P in cocoa plantation may be due to the application of fertilizers such as Diammonium phosphate (DAP) and organic manure (poultry manure and cow dung), while the detected fractions of Avl P under secondary forest can be associated with phosphorus fixation due to the higher SOM concentrations (Tellen et al., 2018). The incidence of higher Avl P in the cocoa plantation and secondary forest soils could also be credited to the presence of high SOM contents (Kidanemariam et al., 2012). The lower Avl P fractions in quarry site are the outcome of years of land use and reduced degree of nutrient export by the limited vegetation (Melo et al., 2017). Avl P demonstrated significant variation at the topsoil under different land uses ( $p>0.05)$. This infers the effect of the examined land uses on Avl P. However, in examining chemical and biochemical properties of soils developed from different lithologies in Northwestern Spain (Galicia), Cardelli et al. (2017) reported low values of available $\mathrm{P}$ (with the exception of the soils on serpentinite and phyllite). They opined that this circumstance was ascribed to both parent rocks and environmental situations.

\section{Effective exchange capacity cation (ECEC)}

Effective exchange capacity cation concentrations in soils on the topsoil were as follows plantation > secondary forest > quarry site (Table 1). ECEC values of cocoa plantation could be attributed to the high $\mathrm{pH}$ mean value of topsoil and the allophane-clay minerals of the investigated soils (Assen \& Tegene, 2008). The low level of SOM and the prevalence of the low 
activity clay mineral kaolinite in the study sites could have resulted in the low ECEC fractions (Ideriah \& Abere, 2017).

\section{$\mathrm{Ca}, \mathrm{Mg}, \mathrm{Na}$ and $\mathrm{K}$}

Higher mean values of $\mathrm{Na}\left(33.05 \mathrm{cmol} \mathrm{kg}^{-1}\right), \mathrm{Mg}\left(18.57 \mathrm{cmol} \mathrm{kg}^{-1}\right)$ and $\mathrm{K}\left(14.24 \mathrm{cmol} \mathrm{kg}^{-1}\right)$ were observed in the topsoil of cocoa plantation, whereas $\mathrm{Ca}\left(9.08 \mathrm{cmol} \mathrm{kg}^{-1}\right)$ was highest in secondary forest (Table 1). This implies the various extent of influence of the land uses on exchangeable cations and may also be attributed to the higher mean $\mathrm{pH}$ values of the topsoil. The lower values of $\mathrm{K}$ in the quarry site could be credited to the incidences of low ECEC in its soils. The concentrations of $\mathrm{Ca}, \mathrm{Mg}, \mathrm{Na}$ and $\mathrm{K}$ in secondary forest may be due to the impacts of tree felling in the secondary forest and minimal soil cover in the quarry site (Orobator \& Odjugo, 2015).

\section{$\mathrm{Zn}, \mathrm{Fe}, \mathrm{Cu}$ and $\mathrm{Mn}$}

Generally, in the topsoil of the land uses, apart from higher mean value of $\mathrm{Zn}\left(1.24 \mathrm{mg} \mathrm{kg}^{-1}\right)$ observed in quarry site; $\mathrm{Fe}\left(80.83 \mathrm{mg} \mathrm{kg}^{-1}\right), \mathrm{Cu}\left(6.13 \mathrm{mg} \mathrm{kg}^{-1}\right)$ and $\mathrm{Mn}\left(1.89 \mathrm{mg} \mathrm{kg}^{-1}\right)$ were higher in cocoa plantation (Table 1). This infers the varied degree of effects of the investigated land uses on the micronutrients. In addition to the land uses, the micronutrient content of soils could also be impacted by several factors among which are SOM content, soil $\mathrm{pH}$ and clay content (Fisseha, 1992).

\section{Conclusion and Recommendations}

The current study indicates varied effects of secondary forest, cocoa plantation and quarry site on the quality of plateau soils. However, owing to mining activities, quarry site soils had lower 
Ghana Journal of Geography Vol. 13 (3), 2021 pages 22- 41

contents of SOM, SOC, TN, Avl P, ECEC, K and Mn. Fe, Cu and Zn were lower in secondary forest. However, higher values of $\mathrm{Na}$ and ECEC were observed in cocoa plantation. Sand, clay and Avl P varied significantly in the topsoil among the land uses. The soils of the land uses on the plateau were acidic with low SOM status. The research concluded that the examined soils were not fertile. To enhance the quality of the soils, remediation processes such as the use of organic amendments (plant and animal remains) and liming is suggested. This will aid in improving the SOM status of plateau soils, thus making more nutrients available for plant uptake. The cultivation of acid-tolerant crops on the plateau soils of Ososo is also recommended. 


\section{References}

Alexander, M. J. and Kidd, A. D. (2000). Farmers capability and institutional incapacity in reclaiming disturbed land on the Jos Plateau, Nigeria. Journal of Environmental Management, 59: 141 - 155.

Assen, M. and Tegene, B. (2008). Characteristics and classification of the soils of the plateau of Simen mountains national park, Ethiopia. Ethiopian Journal of Science, 31(2): 89 $-102$.

Bangroo, S. A., Najar, G. R. and Rasool, A. (2017). Effect of altitude and aspect on soil organic carbon and nitrogen stocks in the Himalayan Mawer Forest Range. Catena, 158: 63 - 68 .

Blake, G.R. and Hartge, K.H. (1996).Bulk density In Klute, A Ed., Methods of Soil Analysis. Part 1-Physical and Mineralogical Methods, $2^{\text {nd }}$ Edition, Agronomy Monograph 9,American Society of Agronomy -Soil Science Society of America, Madison, 363382.

Brady, N. C. and Weil, R. R. (2002). The nature and properties of soils, $8^{\text {th }}$ Ed. New Jersey, Prentice- Hall Inc., USA. p 960.

Bray, R. A. and Kurtz, L. T. (1945). Determination of total organic and available forms of phosphorus in soils'. Soil Science, 59: 39 - 45.

Cardelli, V., Cocco, S., Agnelli, A., Nardi, S., Pizzeghello, D., Maria, J. Fernández-Sanjurjo and Corti, G. (2017). Chemical and biochemical properties of soils developed from different lithologies in northwestern Spain (Galicia) Forests, 8(135): 1 - 16.

Coates, T, M., Hagan, D.L., Aust, W.M., Johnson, A., Keen, J.C., Chow, A. T and Dozier, J. H. (2018). Mineral soil chemical properties as influenced by long-term use of prescribed fire with differing frequencies in a Southeastern Coastal Plain Pine Forest. Forests, 9, (739):1-14.

Egli, M. and Poulenard, J. (2017). Characteristics of mountainous landscapes. The International Encyclopedia of Geography. Ed. Richardson, D., Castree, N., Michael, F. Goodchild, Audrey Kobayashi, Weidong L. and Richard A. M. John Wiley and Sons, Ltd.

Essoka, A., Ibanga, I. and Amalu, U. (2009). Physical properties of the mountain soils of Cross River State, Nigeria. Being a paper presented at the $35^{\text {th }}$ annual conference of the SSCN, at Federal University of Technology, Minna.

European Commission, (2007). Factors that determine sustainable use of soil. Being an article presented in $65^{\text {th }}$ European Commission Conference.

Ezeaku, P.I. (2015). Evaluation of agro-ecological approach to soil quality assessment for sustainable land use and management system. Sci. Res. Essays, 10: 501-512.

Fisseha, I. (1992). Macro and micronutrients distribution in Ethiopian Vertisols landscapes. Ph.D. Dissertation submitted to Institute for Bondenkunde and Standortslehre, University of Hohenheim, Germany. p 201.

Francek, M. A., Makima, A. B., Pan, V. and Hanko, J. H. (1994). Small town lead levels: A case study from the homes of preschoolers in MT-pleasant Michigan. Environmental Pollution, 1: 159. 
Griffithsa, R. P., Madritch, M. D. and Swansona, A. K. (2009). The effects of topography on forest soil characteristics in the Oregon Cascade Mountains (USA): Implications for the effects of climate change on soil properties. Forest Ecology and Management, 257: 1-7.

Hassan, A.M., Raji, B.A., Malgwi, W.B and Agbenin, J.O. (2015).The Basaltic Soils of Plateau State, Nigeria; Properties, Classification and Management Practices. Journal of Soil Science and Environmental Management. 6 (1):1-8.

Hayatu N.G., Abdulwahab M.O., Haruna F.D., Anka A.B.,Jabbi F.F., Bai Y.J.,Darma A.I., Dahiru S. and Shawai R.S.( 2020). Impact of different land use types on some selected soil physical and chemical properties of soils in Kware Local Government Area, Sokoto State, Nigeria FUDMA Journal of Agriculture and Agricultural Technology, 6(2): 1-14.

Haynes, R. J., and Naidu, R. (1998). Influence of lime, fertilizer and manure applications on soil organic matter content and soil physical conditions: A review. Nutritional Cycle Agroecosystem 51: 123 - 137.

He, X., Hou, E., Liu, Y. and Wen, D. (2016). Altitudinal patterns and controls of plant and soil nutrient concentrations and stoichiometry in subtropical China. Scientific Reports, 6: 24261.

Heimsath, A. M., Roman, A., Dibiase, K. X. and Whiple, G. (2012). Soil production limits and the transition to bed-rock dominated landscapes. Nature Geosciences. 5:210214.

Hillel, D. A. (1980). Fundamentals of soil physics. Harcourt Brace Jovanovich Publisher, Academic Press, Inc. San Diego. p 413.

Ideriah, T. J. K. and Abere, S. A. (2017). Physicochemical properties and selected heavy metals in tin-mine spoil soils around Jos Plateau, Nigeria. International Journal of Environmental and Agriculture Research, 3(8): 2454 - 1850.

Idoga, S. and Azagaku, D. E. (2005). Characterization and classification of soils of Janta area, Plateau State of Nigeria. Nigerian Journal of Soil Science, 15: 116 - 122.

Ipinmoroti, R. R. and Akanbi, O. S. O. (2019). Influence of neem leaf fortified fertilizers on tea (Camellia sinensis) yield and soil chemical properties. Acta Horticulture, 1253: $141-146$.

Isaac, E. Maina, H., May, D., Bwano, R., Yohanna, R. and Bala, J. E. (2018). Physichochemical properties and trace elements of soils in Mambilla Plateau of Northeastern Nigeria. World Journal of Applied Chemistry, 3(3): 72 - 82.

Isaac, E., Maitera, O. N., Donatus, R. B., Riki, Y. E., Yerima, E. A., Tadzabia, K. and Joseph, B. (2019). Energy dispersive X-Ray fluorescence determination of minor and major elements in soils of Mambilla Plateau Northeastern Nigeria. Journal of Environmental Chemistry and Ecotoxicology, 11(2): 22 - 28.

Jackson,M. L.,(1973).Soil Chemical Analysis.Prentice Hall of India Pub. Ltd.New Delhi, p 498.

Kalhoro, S.A., Xu, X., Chen, W., Hua, R., Raza, S and Ding, K (2017). Effects of Different Land-Use Systems on Soil Aggregates: A Case Study of the Loess Plateau (Northern China) Sustainability, 9 (1349): 1-16. 
Kareem, A. I. (2007). Rattle tree (Albizia lebbeck) effects on soil properties and productivity of Irish potato (Solanum tuberosum) on the Jos Plateau, Nigeria. A Thesis in the Department of Geography and Planning, Faculty of Environmental Sciences, Submitted to the School of Postgraduate Studies, University of Jos, in Partial Fulfillment of the Requirements for the Award of the Degree of Doctor of Philosophy (Ph.D.) in Environmental Resource Planning of the University of Jos.

Kellogg, C.E. (1960).Soil classification and correlation in the soil survey. Soil Science. 89(1):62.

Kidanemariam, A., Gebrekidan, H., Mamo, T. and Kibret, K. (2012). Impact of altitude and land use type on some physical and chemical properties of acidic soils in Tsegede Highlands, Northern Ethiopia. Open Journal of Soil Science, 2: 223 - 233.

Kparmwang, T., Esu, I. E.and Chude, V. O. (1998). Properties, classification and agricultural potential of basaltic soils in semi-arid Nigeria. Journal of Arid Environments, 38(1): $117-128$.

Kumar, S. Suyal, D. C., Yadav, A. Shouche, Y. Goel, R. (2019). Microbial diversity and soil physiochemical characteristic of higher altitude. PLOS ONE, 14(3): 23 -34.

Lal, R. and Stewart, F. (2005). Principles of soil physics. Marcel Dekker, Inc. 18. p 773.

Landon, J. R. (1991). Booker tropical soil manual: A hand book for soil survey and agricultural land evaluation in the tropics and sub-tropics. Longman, New York.

Li Pan, H., Liu, X. L., Cai, Z. Du, F., He, L., Wang, C., Jia, and Li, M. H. (2009). Growth and morphological responses of Fargesia angustissima to altitude in the Wolong nature reserve, southwestern China. Acta Ecologica Sinica, 29: 144 - 149.

Meliyo, J. L., Msanya, B. M., Kimaro, D. N., Massawe, B. H. J., Hieronimo, P., Mulungu, L. S., Deckers, J. and Gulinck, H. (2016). Variability of soil organic carbon with landforms and land use in the Usambara Mountains of Tanzania. 7(9): 123 - 132.

Melo, V. F., Orrutéa, A. G., Motta, A. C. V., Testoni, S. A. (2017). Land use and changes in soil morphology and physical-chemical properties in Southern Amazon. Revista Brasilienira Ciencia do Solo. 41:1 - 14.

Mulat,Y., Kibret,K., Bedadi,B. and Mohammed,M. (2021). Soil quality evaluation under different land use types in Kersa sub-watershed, eastern Ethiopia. Environ Syst Res 10:19.1-11.

Nelson, D. W. and Sommers, L. E. (1982). Organic carbon and soil extracts. In: Methods of soil analysis. Chemical and microbiological properties. Agronomy Monograph No.9, 2nd Edition. American Society of Agronomy, Soil Science Society of America, Madison, WI, USA. 539 - 579, 1982.

Ogbu, O. J., Usman, J., Iji, E. S., Oyetola, S. O. (2017). Variations in morphological and physico-chemical properties of soil as influenced by topography in southern guinea savannah zone of Nigeria. International Journal of Academic Research and Development, 2(2): 116 - 125.

Olowolafe, E. A. (2002). Soil parent materials and soil properties in two separate catchment areas on the Jos Plateau, Nigeria. Geojournal, 56: 201 - 212.

Orobator, P. O. and Odjugo. P. A. O. (2015). Influence of parent materials and land use on exchangeable cations in a tropical environment. International Journal of Geography, Environment and Earth Science, 3 (3 \& 4): 1 - 12. 
Orobator, P. O., Ekpenkhio, E., Odudu, R. O. and Uuzebor, I. (2019). Investigating soil quality indicators' response to perennial cropping systems in lowland areas of northern Edo State, Nigeria. International Journal of Social Sciences, 13(3): 83 96.

Parr, J. F., Papendick, R. I., Hornick, S. B., and Meyer, R. E. (1992). Soil quality: Attributes and relationship to alternative and sustainable agriculture. American Journal of Alternative Agriculture, 7: 5 - 11.

Pauwels, J.M.,Van Ranst.E.,Verloo. M. and Mvondoze. A (1992). Manuel de Laboratoire de Pedologie. Public Agric. 28:75-126.

Rhoades, J. L. (2008). Impacts of deforestation and land cover change on mountain soils in Hrazdan, Armenia. A Report Submitted in Partial Fulfillment of the Requirements for the Degree of Master of Science in Forestry Michigan Technological University.

Roose, E. Barthes, B. (2001). Organic matter management for soil conservation and productivity restoration in Africa: a contribution from francophone research. Nutrient Cycling in Agroecosystems 61: 159 - 170.

Senjobi, B. A. and Ogunkunle, A. O. (2011). Effect of different land use types and their implications on land degradation and productivity in Ogun State, Nigeria. Journal of Agricultural Biotechnology and Sustainable Development, 3(1): 7 - 18.

Simon, B, Groombridge, B., and Lysenko I. (2002). Mountain watch. UNEP World Conservation Monitoring Centre. Google Scholar.

Streb, P., Shang, W., Feierabend, J. and Bligny, R. (1998). Divergent strategies of photo protection in high mountain plants. Planta, 207: 313 - 324.

Tellen, A. V., Bernard P. and Yerima, K. (2018). Effects of land use change on soil physicochemical properties in selected areas in the North West region of Cameroon Environmental Systems Research, 7:(3)1 - 29.

Tesfahunegn G. B and Gebru, T.A. (2020). Variation in soil properties under different cropping

and other land-use systems in Dura catchment, Northern Ethiopia. PLoS ONE 15(2):

$1-27$.

Tumayro, M and Tesgaye, D (2021). Impact of land use types and soil depths on selected

Soil physicochemical properties in Fasha District, Konso Zone, Southern Ethiopia.

Journal of Soil Science and Environmental Management.12 (1):10-16.

USDA (1972). Soil survey laboratory methods and procedures for collecting soil samples. Soil Survey Investigation Report No. 1.

USDA (1995). Laboratory methods for soils and folier analysis in long-term environmental monitoring programs.

USDA (nd). Soil bulk density/moisture/aeration. Natural Resources Conservation Services. Soil Quality Kit/Guides for Educators. p3.

Van Noordwijk, M., Hairiah. K., Lusiana, B. and Cadisch, G. (1998). Tree-Soil-Crop interactions in sequential and simultaneous agroforestry systems. In: Bergstrom, L. and Kirchmann, H. (eds) Carbon and Nitrogen Dynamics in Natural and Agricultural Tropical Ecosystems. Cab International. 173-190. 
Vashisht, B.G., Maharjan ,B., Sharma ,S and Kaur,S. (2020). Soil Quality and Its Potential Indicators under Different Land Use Systems in the Shivaliks of Indian Punjab. Sustainability, 12(3490): 1- 13.

Walkey, A. and Black, C.A. (1934). An examination of the methods for determining soil organic matter and a proposal for the modification of the chromic acid titration method. Soil Science, 37: 29 - 38.

Young, D., and Crawford, K. (2004). The role of soils in the stability of ecosystems. Geoderma.134: 77 - 78.

Yüksek, F., Altun, L., Karaöz, O., Şengönül, K., Yüksek, T. and Küçük, M. (2018). The effect of altitude on soil properties and leaf traits in wild Vaccinium arctostaphylos L. populations in the forest understory in Firtına River Basin. International Caucasian Forestry Symposium, Artivin, Turkey. 577 - 583. 